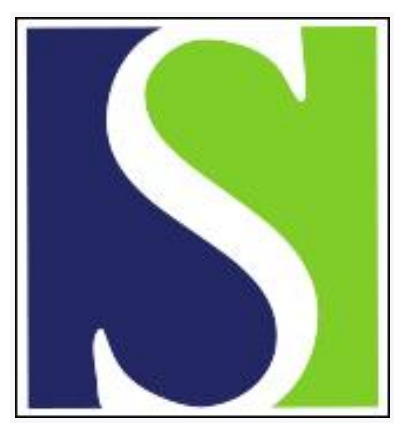

Scand J Work Environ Health 1987;13(2):94-99

https://doi.org/10.5271/sjweh.2067

Issue date: Apr 1987

Mortality of workers exposed to styrene in the manufacture of glass-reinforced plastics.

by Coggon D, Osmond C, Pannett B, Simmonds S, Winter PD, Acheson ED

This article in PubMed: www.ncbi.nlm.nih.gov/pubmed/3602970

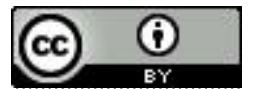




\title{
Mortality of workers exposed to styrene in the manufacture of glass-reinforced plastics
}

\author{
by David Coggon, PhD, MRCP, Clive Osmond, MA, PhD, Brian Pannett, MSc, Shirley Simmonds, \\ BSc, Paul D Winter, MSc, E Donald Acheson, DM FRCP ${ }^{1}$
}

\begin{abstract}
COGGON D, OSMOND C, PANNETT B, SIMMONDS S, WINTER PD, ACHESON ED. Mortality of workers exposed to styrene in the manufacture of glass-reinforced plastics. Scand $J$ Work Environ Health 13 (1987) 94-99. Epidemiologic studies have suggested an increased risk of leukemia and lymphoma among workers exposed to styrene. In a further exploration of this possible hazard, an analysis was conducted of the mortality among 7949 men and women employed during 1947-1984 in eight British companies manufacturing glass-reinforced plastics. The subjects were identified from company files and traced to the end of 1984 through National Health Service and National Insurance records. The overall mortality in the cohort was less than in the national population (693 deaths observed, 830.1 expected) as was mortality from cancer (181 deaths observed, 223.7 expected). In particular, there was a deficit of deaths from lymphoid and hemopoietic cancer ( 6 observed, 14.9 expected). The small excess of lung cancer ( 89 deaths observed, 80.1 expected) was not statistically significant and can probably be attributed to chance. Among 3494 hand laminators (the job with the highest exposure to styrene) there was one death from lymphoma and none from leukemia. The findings do not exclude the possibility that styrene is a human carcinogen, but give no support to the hypothesis that it causes leukemia and lymphoma.
\end{abstract}

Key terms: epidemiologic study, lung cancer, leukemia, lymphoma.

Styrene has been produced commercially for more than 50 years and is used mainly in the production of plastics, resins, and synthetic rubbers. In 1977 worldwide production was estimated at 7 million tons (4). The highest exposures to the compound usually occur in industry, but contact with styrene is not confined to the workplace. Styrene-based resins are sold for domestic use as woodfillers, and low levels of styrene have been recorded in foods packaged in polystyrene containers.

The discovery that vinyl chloride causes angiosarcoma of the liver raised concern that styrene, with its somewhat similar chemical structure, might also be carcinogenic. Suspicions have been increased by the demonstration that styrene is mutagenic (5), possibly through metabolic activation to styrene oxide (9). Moreover, increased rates of chromosome aberrations have been found in workers exposed to styrene $(3,8)$. On the other hand, animal tests of carcinogenicity have been inconclusive (5).

Several epidemiologic investigations have suggested high rates of leukemia or lymphoma among people working with styrene $(2,6,11)$. However, the total number of reported cases is small, and a confounding effect of other chemicals such as benzene cannot always be excluded. There is thus a need for additional epidemiologic data on this possible hazard.

\footnotetext{
${ }^{1}$ Environmental Epidemiology Unit of the Medical Research Council, University of Southampton, Southampton General Hospital, Southampton SO9 4XY, United Kingdom.
}

Reprint requests to: Dr D Coggon, MRC Environmental Epidemiology Unit, University of Southampton, Southampton General Hospital, Southampton SO9 4XY, UK.
The best opportunity to study the chronic health effects of styrene is in the manufacture of glassreinforced plastics, since exposures are higher than in other industries and the range of potential confounders is smaller. We have examined the mortality and cancer incidence of employees at eight British companies making a variety of products from glassreinforced plastics.

\section{Subjects and methods}

Details of the companies surveyed and the criteria by which the study cohort was defined are given in table 1 . We identified subjects from personnel and wage records and abstracted each person's name, address, sex, date of birth, and National Insurance number, as far as the information was available. We also recorded a history of the jobs which each subject had held during his or her employment, including the dates of starting and finishing work.

With help from the management and staff of the factories, and prior to our analysis of mortality and cancer incidence, we classified jobs according to their potential for exposure to styrene. Four grades of exposure were distinguished - high (hand laminators), moderate (subjects who regularly entered areas of glass-reinforced plastics production or worked close to laminating operations although not actively engaged in laminating), low (subjects who occasionally entered areas of glass-reinforced plastics production or experienced a constant but low-level exposure at a situation remote from the laminating operation), and background (no exposure other than the background 
level in the factory as a whole). No hygiene data were available for the early years of the study period, but since 1975 styrene concentrations had been measured at factories A, B, C, E, and F. On the basis of these measurements we estimate that our high exposure category corresponds to an 8 -h time-weighted average exposure of $40-100 \mathrm{ppm}$. Where personal respiratory protection was provided, it took the form of particulate filters and would not have affected exposure to styrene. Of the other possible hazards to which the study population was exposed, the most important were glass fiber, acetone, methyl ethyl ketone, organic peroxides, and (at factories $\mathrm{C}$ and $\mathrm{F}$ only) asbestos.

Members of the cohort were traced through the National Health Service (NHS) Central Register and National Insurance Index, and their vital status on $31 \mathrm{De}-$ cember 1984 was determined. The Office of Population Censuses and Surveys provided us with copies of the death certificates of subjects who had died, with the underlying cause of death coded to the ninth revision of the International Classification of Diseases. In addition it notified us of any cancers that had been registered in the study population during the period of follow-up.

The mortality of the cohort was compared with that of the national population of England and Wales by the person-years method and was examined in relation to length and grade of potential exposure to styrene.
Confidence intervals and statistical significance were calculated by the usual techniques based on the Poisson distribution.

\section{Results}

The study population comprised 8354 subjects, but $405(4.8 \%)$ could not be included in the analysis because their sex, date of birth, or date of first employment was not available from the company records. A further 210 subjects could not be traced in the files of the NHS Central Register or National Insurance Index and could only be followed to the date on which they were last employed by one of the companies under investigation. One hundred and seventy-one members of the cohort emigrated during the study period and were followed to the time of emigration. Of the 7949 subjects whose records were suitable for analysis, 6638 were men and 1311 were women.

Details of the follow-up achieved at individual companies are given in table 1 . The personnel records held by company $\mathrm{D}$ often lacked important items of information, and as a consequence the proportion of its employees excluded from the analysis or untraced was much higher than elsewhere. In view of the possible biases resulting from this loss, the findings for company D are presented separately from those of the other companies.

Table 1. Description of cohort and follow-up rates by company.

\begin{tabular}{|c|c|c|c|c|c|c|c|}
\hline Company & Location & Product & $\begin{array}{l}\text { Period } \\
\text { in } \\
\text { which } \\
\text { styrene } \\
\text { was used }\end{array}$ & $\begin{array}{l}\text { Subjects included } \\
\text { in cohort }\end{array}$ & $\begin{array}{l}\text { Number of } \\
\text { subjects }^{a}\end{array}$ & $\begin{array}{l}\text { Proportion } \\
\text { of subjects } \\
\text { suitable for } \\
\text { analysis (\%) }\end{array}$ & $\begin{array}{l}\text { Proportion } \\
\text { of subjects } \\
\text { suitable for } \\
\text { analysis and } \\
\text { traced }(\%)\end{array}$ \\
\hline A & Staffordshire & Car bodies & 1953-present & $\begin{array}{l}\text { All employees, } \\
1 \text { January } 1967- \\
31 \text { December } 1981\end{array}$ & 950 & 100.0 & 99.7 \\
\hline B & Lancashire & $\begin{array}{l}\text { Panels for } \\
\text { vehicles }\end{array}$ & $1956-1981$ & $\begin{array}{l}\text { All employees in } \\
\text { the glass-reinforced } \\
\text { plastics department, } \\
1 \text { January } 1956- \\
\text { 31 December } 1981\end{array}$ & 524 & 100.0 & 98.5 \\
\hline $\mathrm{C}$ & Avon & $\begin{array}{l}\text { Car bodies, } \\
\text { fuel tanks and } \\
\text { other moldings }\end{array}$ & 1960-present & $\begin{array}{l}\text { All employees, } \\
1 \text { January } 1963- \\
29 \text { February } 1984\end{array}$ & 3206 & 97.7 & 97.2 \\
\hline D & Dorset & Boats & 1947-present & $\begin{array}{l}\text { All employees, } \\
1 \text { January } 1947- \\
1 \text { July } 1982\end{array}$ & 979 & 76.6 & 61.9 \\
\hline E & Avon & $\begin{array}{l}\text { Panels for } \\
\text { vehicles }\end{array}$ & 1968-present & $\begin{array}{l}\text { All employees, } \\
1 \text { January } 1968- \\
1 \text { April } 1982\end{array}$ & 525 & 98.7 & 98.3 \\
\hline$F$ & West Yorkshire & $\begin{array}{l}\text { Pipes and } \\
\text { vessels }\end{array}$ & 1954-present & $\begin{array}{l}\text { All employees, } \\
1 \text { January } 1958- \\
1 \text { September } 1982\end{array}$ & 495 & 91.1 & 88.5 \\
\hline $\mathrm{G}$ & $\begin{array}{l}\text { Nottingham- } \\
\text { shire }\end{array}$ & $\begin{array}{l}\text { Fabrications } \\
\text { and decorative } \\
\text { panels }\end{array}$ & 1961-present & $\begin{array}{l}\text { All employees, } \\
1 \text { July } 1977- \\
30 \text { October } 1982\end{array}$ & 203 & 84.2 & 83.7 \\
\hline $\mathrm{H}$ & Bedfordshire & $\begin{array}{l}\text { Fabrications } \\
\text { and moldings }\end{array}$ & $1953-1960$ & $\begin{array}{l}\text { All employees, } \\
1 \text { January } 1953- \\
31 \text { December } 1960\end{array}$ & 1478 & 98.7 & 97.1 \\
\hline
\end{tabular}

\footnotetext{
a Six subjects each worked at two companies - four at factories $\mathrm{C}$ and $\mathrm{E}$, one at factories $\mathrm{C}$ and $\mathrm{H}$, and one at factories $\mathrm{B}$
} and $\mathrm{D}$. 
Of the subjects included in the analysis, 5434 worked in jobs entailing exposure to styrene at levels above background. Table 2 shows the distribution of these men and women according to the length of their exposure to styrene, and also according to the most highly exposed job in which each worked. A total of 2458 subjects worked in exposed occupations for at least 12 months, and 3494 were at some time employed in jobs with high exposure.

At the companies where the follow-up was reasonably complete (A-C, E-H), the overall mortality was less than that of the national population (637 deaths observed, 768.8 expected) as was mortality from cancer (167 deaths observed, 208.1 expected) and from the other major disease categories (table 3). The findings for company D were similar, apart from a small and statistically nonsignificant excess of deaths due to digestive disease (5 deaths observed, 1.6 expected).

Table 4 shows the mortality of the cohort from specific cancers, and tables 5, 6, 7, and 8 give a breakdown of the cancer deaths according to grade and duration of exposure to styrene, time since first ex- posure, and calendar period of first exposure. Several tumors occurred more frequently than would have been expected from the national rates, but in no instance was the risk statistically significant at a $5 \%$ level.

The most prominent excess was for lung cancer $(89$ deaths observed in the entire cohort, 80.1 expected). The death rates from bronchial carcinoma were the highest for subjects with moderate and high exposure to styrene, although the dose-response relationship was not entirely consistent (table 5). The raised rate was concentrated particularly among workers with one to nine years of employment in an exposed job (table 6). Among subjects exposed for ten or more years, there was no excess. Nor did the rates of lung cancer increase with time since first exposure (table 7). The highest standardized mortality ratio was found for workers first exposed after 1969 (table 8). When the expected mortality rates were corrected by the 1968-1978 standardized mortality ratios for lung cancer in the local authority areas in which each factory was situated, the total number of expected lung cancer deaths was virtually unchanged at 80.0 .

Table 2. Distribution of the subjects included in the analysis of mortality by length and grade of exposure to styrene. ${ }^{2}$

\begin{tabular}{|c|c|c|c|c|c|c|c|}
\hline \multirow{2}{*}{ Company } & \multicolumn{4}{|c|}{ Length of potential exposure to styrene } & \multicolumn{3}{|c|}{$\begin{array}{l}\text { Highest exposure grade in which subject } \\
\text { worked }\end{array}$} \\
\hline & $<1$ year & $1-9$ years & $\geq 10$ years & Unknown & Low & Moderate & High \\
\hline $\begin{array}{l}\text { A } \\
B \\
C \\
D \\
E \\
F \\
G \\
H\end{array}$ & $\begin{array}{r}276 \\
252 \\
1214 \\
337 \\
145 \\
40 \\
21 \\
278\end{array}$ & $\begin{array}{r}434 \\
200 \\
630 \\
241 \\
253 \\
81 \\
62 \\
154\end{array}$ & $\begin{array}{r}213 \\
36 \\
91 \\
26 \\
16 \\
14 \\
9 \\
0\end{array}$ & $\begin{array}{r}2 \\
4 \\
252 \\
104 \\
12 \\
33 \\
8 \\
1\end{array}$ & $\begin{array}{r}244 \\
125 \\
538 \\
299 \\
109 \\
26 \\
3 \\
34\end{array}$ & $\begin{array}{r}168 \\
10 \\
220 \\
14 \\
95 \\
35 \\
13 \\
11\end{array}$ & $\begin{array}{r}513 \\
357 \\
+429 \\
395 \\
222 \\
107 \\
84 \\
388\end{array}$ \\
\hline All companies & 2560 & 2053 & 405 & 416 & 1376 & 564 & 3494 \\
\hline
\end{tabular}

a Two thousand five hundred and fifteen subjects with only background exposure have been excluded. Five subjects worked in exposed jobs at two companies.

Table 3. Mortality from major disease categories. (SMR = standardized mortality ratio)

\begin{tabular}{|c|c|c|c|c|c|c|c|c|}
\hline \multirow[b]{2}{*}{ Disease category ${ }^{a}$} & \multicolumn{4}{|c|}{ Companies $\mathrm{A}-\mathrm{C}, \mathrm{E}-\mathrm{H}$} & \multicolumn{4}{|c|}{ Company D } \\
\hline & $\begin{array}{l}\text { Observed } \\
\text { deaths }\end{array}$ & $\begin{array}{l}\text { Expected } \\
\text { deaths }\end{array}$ & SMR & $\begin{array}{c}95 \% \\
\text { confidence } \\
\text { interval }\end{array}$ & $\begin{array}{l}\text { Observed } \\
\text { deaths }\end{array}$ & $\begin{array}{l}\text { Expected } \\
\text { deaths }\end{array}$ & SMR & $\begin{array}{c}95 \% \\
\text { confidence } \\
\text { interval }\end{array}$ \\
\hline $\begin{array}{l}\text { All causes of death } \\
(0-999)\end{array}$ & 637 & 768.8 & 83 & $77-89$ & 56 & 61.3 & 91 & $69-119$ \\
\hline $\begin{array}{l}\text { All neoplasms } \\
(140-239)\end{array}$ & 167 & 208.1 & 80 & $69-93$ & 14 & 15.6 & 90 & $49-150$ \\
\hline $\begin{array}{l}\text { Ischemic heart disease } \\
(410-414)\end{array}$ & 217 & 235.2 & 92 & $80-105$ & 15 & 19.2 & 78 & $44-129$ \\
\hline $\begin{array}{l}\text { Cerebrovascular } \\
\text { disease }(430-438)\end{array}$ & 53 & 64.6 & 82 & $61-107$ & 3 & 4.8 & 62 & $13-183$ \\
\hline $\begin{array}{l}\text { Respiratory disease } \\
(460-519)\end{array}$ & 60 & 85.8 & 70 & $53-90$ & 3 & 6.7 & 45 & $9-130$ \\
\hline $\begin{array}{l}\text { Digestive disease } \\
(008-009,530-579)\end{array}$ & 17 & 20.6 & 82 & $48-132$ & 5 & 1.6 & 304 & $99-710$ \\
\hline $\begin{array}{l}\text { Injury and poisoning } \\
(800-999)\end{array}$ & 41 & 50.5 & 81 & $58-110$ & 4 & 5.1 & 79 & $22-202$ \\
\hline
\end{tabular}

a The code of the International Classification of Diseases, ninth revision, is given in parentheses. 
Table 4. Mortality from cancer. (SMR = standardized mortality ratio)

\begin{tabular}{|c|c|c|c|c|c|c|c|c|c|c|}
\hline \multirow{3}{*}{$\begin{array}{l}\text { Cancer }^{\mathrm{a}} \\
\text { Esophagus (150) }\end{array}$} & \multicolumn{5}{|c|}{ Companies $\mathrm{A}-\mathrm{C}, \mathrm{E}-\mathrm{H}$} & \multicolumn{5}{|c|}{ Company D } \\
\hline & \multirow{2}{*}{$\begin{array}{c}\begin{array}{c}\text { Observed } \\
\text { deaths }^{b} \\
(\mathrm{~N})\end{array} \\
3\end{array}$} & \multirow{2}{*}{$\begin{array}{c}\begin{array}{c}\text { Expected } \\
\text { deaths } \\
(\mathrm{N})\end{array} \\
5.77\end{array}$} & \multirow{2}{*}{$\begin{array}{c}\text { SMR } \\
52\end{array}$} & \multicolumn{2}{|c|}{$\begin{array}{l}95 \% \\
\text { confidence } \\
\text { interval }\end{array}$} & \multirow{2}{*}{$\begin{array}{c}\begin{array}{c}\text { Observed } \\
\text { deathsc } \\
(\mathrm{N})\end{array} \\
1\end{array}$} & \multirow{2}{*}{$\begin{array}{c}\begin{array}{c}\text { Expected } \\
\text { deaths } \\
(\mathbf{N})\end{array} \\
0.45\end{array}$} & \multirow{2}{*}{ SMR } & \multicolumn{2}{|c|}{$\begin{array}{c}95 \% \\
\text { confidence } \\
\text { interval }\end{array}$} \\
\hline & & & & $11-$ & 152 & & & & $6-$ & 1227 \\
\hline Stomach (151) & 14 & 19.22 & 73 & $40-$ & 122 & 1 & 1.57 & 64 & $2-$ & 355 \\
\hline Large intestine (153) & 9 & 13.02 & 69 & $32-$ & 131 & - & 0.95 & - & $0-$ & 388 \\
\hline Rectum (154) & 6 & 8.98 & 67 & $25-$ & 145 & - & 0.70 & - & $0-$ & 524 \\
\hline Pancreas (157) & 4 & 8.60 & 47 & $13-$ & 119 & 1 & 0.66 & 152 & $4-$ & 845 \\
\hline Larynx (161) & 2 & 1.73 & 116 & $14-$ & 418 & - & 0.15 & - & $0-$ & 2527 \\
\hline $\begin{array}{l}\text { Lung, pleura and } \\
\text { mediastinum } \\
(162-164)\end{array}$ & 83 & 74.04 & 112 & $89-$ & 139 & 6 & 6.02 & 100 & $37-$ & 217 \\
\hline Melanoma (172) & 2 & 1.68 & 119 & $14-$ & 430 & - & 0.13 & - & $0-$ & 2784 \\
\hline $\begin{array}{l}\text { Other skin cancer } \\
(173)\end{array}$ & 2 & 0.56 & 357 & $43-1$ & 290 & - & 0.05 & - & $0-$ & 8127 \\
\hline Breast $(174-175)$ & 4 & 8.73 & 46 & $12-$ & 117 & - & 0.03 & 一 & $0-$ & 10810 \\
\hline Cervix $(180)$ & 2 & 1.87 & 107 & $13-$ & 386 & - & 0.00 & - & $0-1$ & 29800 \\
\hline Ovary (183) & 4 & 2.69 & 149 & $41-$ & 381 & - & 0.00 & - & $0-$ & 78050 \\
\hline Prostate (185) & 3 & 7.40 & 41 & $8-$ & 118 & 1 & 0.64 & 157 & $4-$ & 875 \\
\hline Bladder (188) & 3 & 6.52 & 46 & $9-$ & 134 & - & 0.52 & - & $0-$ & 703 \\
\hline Kidney (189) & 3 & 3.64 & 82 & $17-$ & 241 & - & 0.29 & - & $0-$ & 1258 \\
\hline $\begin{array}{l}\text { Brain and nervous } \\
\text { system }(191-192)\end{array}$ & 5 & 5.96 & 84 & $27-$ & 196 & 2 & 0.50 & 403 & $49-$ & 1454 \\
\hline $\begin{array}{l}\text { Hodgkin's disease } \\
\text { (201) }\end{array}$ & 1 & 2.19 & 46 & $1-$ & 254 & - & 0.21 & 一 & $0-$ & 1728 \\
\hline $\begin{array}{l}\text { Non-Hodgkin's } \\
\text { Iymphoma }(200,202)\end{array}$ & 一 & 3.90 & - & $0-$ & 95 & 1 & 0.32 & 311 & $8-$ & 1733 \\
\hline Myeloma (203.0) & 1 & 2.12 & 47 & $1-$ & 263 & - & 0.16 & - & $0-$ & 2357 \\
\hline Leukemia (204-208) & 3 & 5.54 & 54 & $11-$ & 158 & - & 0.46 & - & $0-$ & 801 \\
\hline
\end{tabular}

a The code of the International Classification of Diseases, ninth revision, is given in parentheses.

b In addition one subject died from cancer of the mouth, one from unspecified digestive cancer, one from testicular cancer, and ten from carcinomatosis with unknown primary.

$c$ In addition one subject died from cancer of the small intestine.

Deaths from lymphoma, myeloma, and leukemia all occurred less frequently than expected (table 4). Altogether six subjects died from lymphoid and hemopoietic malignancies. In addition, a further eight such cancers were registered among members of the cohort who were still alive at the end of the follow-up period or who had died from other causes. If these cases are added to the six deaths, the total is still less than the 14.9 deaths expected. Only one of the six observed deaths occurred in a subject with high exposure to styrene - a hand laminator from Company D who died of non-Hodgkin's lymphoma.

\section{Discussion}

This mortality study is statistically more powerful than previously reported surveys of styrene workers, with more than 200 deaths expected among the highly exposed group of hand laminators. Our estimates of the exposure levels associated with this occupation were based upon measurements made since 1975 at five of the eight factories studied, and they are in broad agreement with those which have been found in similar circumstances by other investigators $(10,12,13,15)$. There is no reason to believe that work conditions were better in the earlier years of the study period or at the factories for which no hygiene data were available.

A possible weakness of the investigation is the incomplete follow-up achieved, particularly at factory D. This failure was due largely to deficiencies in records made at the time of employment - for example omission of full first names or date of birth - and as such is unlikely to have been biased in respect of subsequent mortality. Nevertheless, we felt it safer to analyze the results for factory D separately. Of the 7376 subjects from the other seven companies, $96.7 \%$ were both traced and suitable for analysis.

The death rates of the cohort were lower than those of the national population for all the major disease categories, including cancer. This deficit probably reflects a healthy worker effect, although there was little increase in the standardized mortality ratios when allowance was made for a latency of 10 or 20 years from first exposure to styrene.

Our a priori suspicions of carcinogenicity centered on the risk of lymphoma and leukemia suggested by 
Table 5. Mortality from selected cancers by grade of ex posure to styrene - Companies $\mathrm{A}-\mathrm{C}$ and $\mathrm{E}-\mathrm{H} \cdot{ }^{\mathrm{a}}(\mathrm{O}=$ observed number of deaths, SMR = standardized mortality ratio)

\begin{tabular}{|c|c|c|c|c|c|c|c|c|}
\hline \multirow{3}{*}{ Cancer } & \multicolumn{8}{|c|}{ Grade of exposure } \\
\hline & \multicolumn{2}{|c|}{$\begin{array}{l}\text { Back- } \\
\text { ground }\end{array}$} & \multicolumn{2}{|c|}{ Low } & \multicolumn{2}{|c|}{ Moderate } & \multicolumn{2}{|c|}{ High } \\
\hline & 0 & SMR & 0 & SMR & 0 & SMR & 0 & SMR \\
\hline Esophagus & 1 & 39 & - & - & - & - & 2 & 121 \\
\hline Stomach & 5 & 55 & 5 & 168 & 2 & 99 & 2 & 39 \\
\hline Large intestine & - & - & 3 & 160 & 1 & 81 & 5 & 140 \\
\hline Rectum & 1 & 24 & 2 & 146 & 1 & 108 & 2 & 82 \\
\hline Pancreas & 2 & 51 & 1 & 74 & - & - & 1 & 41 \\
\hline Larynx & 1 & 130 & - & - & 1 & 526 & - & - \\
\hline $\begin{array}{l}\text { Lung, pleura } \\
\text { and mediastinum }\end{array}$ & 32 & 100 & 13 & 104 & 13 & 150 & 25 & 120 \\
\hline Melanoma & 2 & 303 & - & - & - & - & - & - \\
\hline Other skin cancer & 2 & 741 & - & - & - & - & - & - \\
\hline Breast & 2 & 33 & - & - & - & - & 2 & 84 \\
\hline Cervix & 1 & 77 & - & - & - & - & 1 & 196 \\
\hline Ovary & 2 & 105 & - & - & - & - & 2 & 282 \\
\hline Prostate & 1 & 27 & - & - & - & - & 2 & 120 \\
\hline Bladder & 2 & 65 & - & - & - & - & 1 & 60 \\
\hline Kidney & 3 & 196 & - & - & - & - & - & - \\
\hline $\begin{array}{l}\text { Brain and } \\
\text { nervous system }\end{array}$ & 1 & 43 & 1 & 105 & 1 & 182 & 2 & 94 \\
\hline Hodgkin's disease & - & - & - & - & 1 & 556 & - & - \\
\hline Myeloma & - & - & - & - & 1 & 455 & - & - \\
\hline Leukemia & 2 & 84 & 1 & 119 & - & - & - & - \\
\hline All neoplasms & 67 & 70 & 30 & 95 & 22 & 104 & 48 & 81 \\
\hline
\end{tabular}

a The subjects have been classified according to the most highiy exposed job in which they worked.

Table 7. Mortality from selected cancers by time since first exposure to styrene - Companies $\mathrm{A}-\mathrm{C}$ and $\mathrm{E}-\mathrm{H} . \mathrm{O}=$ number of observed deaths, SMR = standardized mortality ratio)

\begin{tabular}{|c|c|c|c|c|c|c|c|c|}
\hline \multirow{3}{*}{ Cancer } & \multicolumn{8}{|c|}{ Time since first exposure } \\
\hline & \multicolumn{2}{|c|}{$\leq 9$ years } & \multicolumn{2}{|c|}{$\begin{array}{l}10-19 \\
\text { years }\end{array}$} & \multicolumn{2}{|c|}{$\geq 20$ years } & \multicolumn{2}{|c|}{ Total } \\
\hline & 0 & SMR & 0 & SMR & 0 & SMR & 0 & SMR \\
\hline Esophagus & 1 & 88 & 1 & 72 & - & - & 2 & 63 \\
\hline Stomach & 4 & 100 & 4 & 97 & 1 & 61 & 9 & 92 \\
\hline Large intestine & 3 & 120 & 3 & 108 & 3 & 259 & 9 & 139 \\
\hline Rectum & 1 & 56 & 2 & 100 & 2 & 244 & 5 & 109 \\
\hline Pancreas & 1 & 57 & - & - & 1 & 123 & 2 & 44 \\
\hline $\begin{array}{l}\text { Lung, pleura } \\
\text { and mediastinum }\end{array}$ & 20 & 125 & 23 & 131 & 8 & 113 & 51 & 126 \\
\hline Ovary & 1 & 286 & 1 & 286 & - & - & 2 & 253 \\
\hline Prostate & 1 & 101 & - & - & 1 & 100 & 2 & 55 \\
\hline $\begin{array}{l}\text { Brain and } \\
\text { nervous system }\end{array}$ & 3 & 170 & 1 & 75 & - & - & 4 & 115 \\
\hline Hodgkin's disease & 1 & 123 & - & - & - & - & 1 & 78 \\
\hline Myeloma & 1 & 244 & - & - & - & - & 1 & 89 \\
\hline Leukemia & 1 & 68 & - & - & - & - & 1 & 33 \\
\hline All neoplasms & 43 & 98 & 40 & 87 & 17 & 92 & 100 & 93 \\
\hline
\end{tabular}

earlier studies, but in our cohort there were fewer deaths than expected from lymphoid and hemopoietic malignancy. Nor were these cancers concentrated among subjects with the longest and highest exposure to styrene. A precise analysis of cancer incidence (as opposed to mortality) was not possible because of the incompleteness of cancer registration in England and Wales, especially during the early years of the study period. However, if the known occurrences of lym-
Table 6. Mortality from selected cancers by length of exposure to styrene - Companies $\mathrm{A}-\mathrm{C}$ and $\mathrm{E}-\mathrm{H}$. $(\mathrm{O}=$ observed number of deaths, SMR = standardized mortality ratio)

\begin{tabular}{|c|c|c|c|c|c|c|}
\hline \multirow{3}{*}{ Cancer } & \multicolumn{6}{|c|}{ Length of potential exposure ${ }^{a}$} \\
\hline & \multicolumn{2}{|c|}{$<1$ year } & \multicolumn{2}{|c|}{$1-9$ years } & \multicolumn{2}{|c|}{$\geq 10$ years } \\
\hline & 0 & SMR & 0 & SMR & 0 & SMR \\
\hline Esophagus & 1 & 81 & 1 & 70 & - & - \\
\hline Stomach & 6 & 157 & 3 & 66 & - & - \\
\hline Large intestine & 3 & 115 & 5 & 171 & 1 & 149 \\
\hline Rectum & 1 & 55 & 3 & 143 & - & - \\
\hline Pancreas & - & - & 2 & 97 & - & - \\
\hline $\begin{array}{l}\text { Lung, pleura and } \\
\text { mediastinum }\end{array}$ & 15 & 96 & 29 & 154 & 4 & 89 \\
\hline Ovary & 2 & 500 & - & - & - & - \\
\hline Prostate & - & - & 2 & 113 & - & - \\
\hline $\begin{array}{l}\text { Brain and nervous } \\
\text { system }\end{array}$ & 1 & 64 & 3 & 205 & - & - \\
\hline Hodgkin's disease & - & - & 1 & 200 & - & - \\
\hline Myeloma & - & - & 1 & 196 & - & - \\
\hline Leukemia & - & - & 1 & 78 & - & - \\
\hline All neoplasms & 33 & 76 & 56 & 115 & 6 & 53 \\
\hline
\end{tabular}

a Five cancer deaths occurred among the subjects whose length of exposure to styrene was unknown.

Table 8. Mortality from selected cancers by period of first exposure to styrene - Companies $\mathrm{A}-\mathrm{C}$ and $\mathrm{E}-\mathrm{H} .(\mathrm{O}=$ number of observed deaths, SMR = standardized mortality ratio)

\begin{tabular}{|c|c|c|c|c|c|c|}
\hline \multirow{3}{*}{ Cancer } & \multicolumn{6}{|c|}{ Period of first exposure } \\
\hline & \multicolumn{2}{|c|}{$\begin{array}{c}\text { Before } \\
1960\end{array}$} & \multicolumn{2}{|c|}{$\begin{array}{l}1960- \\
1969\end{array}$} & \multicolumn{2}{|c|}{$\begin{array}{l}\text { After } \\
1969\end{array}$} \\
\hline & $\mathrm{O}$ & SMR & $\mathrm{O}$ & SMR & $\mathrm{O}$ & SMR \\
\hline Esophagus & 1 & 75 & 1 & 93 & - & - \\
\hline Stomach & 4 & 87 & 3 & 93 & 2 & 105 \\
\hline Large intestine & 5 & 178 & 4 & 181 & - & - \\
\hline Rectum & 4 & 196 & - & - & 1 & 100 \\
\hline Pancreas & 1 & 51 & - & - & 1 & 98 \\
\hline $\begin{array}{l}\text { Lung, pleura and } \\
\text { mediastinum }\end{array}$ & 21 & 114 & 12 & 88 & 18 & 213 \\
\hline Ovary & 1 & 435 & - & - & 1 & 435 \\
\hline Prostate & 2 & 106 & - & - & - & - \\
\hline $\begin{array}{l}\text { Brain and nervous } \\
\text { system }\end{array}$ & 2 & 171 & 1 & 79 & 1 & 97 \\
\hline Hodgkin's disease & - & - & 1 & 217 & - & - \\
\hline Myeloma & - & - & 1 & 263 & - & - \\
\hline Leukemia & - & - & - & - & 1 & 112 \\
\hline All neoplasms & 43 & 93 & 27 & 73 & 30 & 122 \\
\hline
\end{tabular}

phoma and leukemia among living subjects and subjects who died from other diseases are added to the deaths caused by these tumors, the count of cases still falls short of the number of deaths expected in the cohort. The apparent discrepancy between this finding and the positive results of some previous studies may be a chance effect, but it could also be due to unrecognized confounding exposures in the chemical and plastics industries. In the only other reported survey 
of mortality among glass-reinforced plastics workers (10), no cases of lymphoma or leukemia were found.

As might be expected, several cancers showed standardized mortality ratios that were greater than 100 , but in no instance was the excess mortality statistically significant at a $5 \%$ level. Only two of the observed associations were based on more than three deaths. Four subjects died from ovarian cancer when 2.7 deaths would have been expected. However, two of these women had only background exposure to styrene, and a third had been exposed for less than a year.

Of more interest is the excess mortality attributed to bronchial carcinoma. At companies where followup was acceptably complete, there were 83 deaths from lung tumors, the standardized mortality ratio being 112. The excess was apparent at five of the factories studied (A, B, C, E, and H) and could not be explained by concomitant exposure to asbestos, which was confined to factories $\mathrm{C}$ and $\mathrm{F}$. Unfortunately, no data were available on the smoking habits of the study population, and interpretation must therefore be speculative. It is worth noting, however, that the mortality of the cohort from respiratory disease was well below that of the national population. This finding suggests that the smoking rates were not excessively high. Analysis by level of exposure to styrene gave some indication of a dose-response relationship, but against this evidence must be weighed the lack of an increase in mortality with time since first exposure and the absence of a risk of lung cancer in most previous studies of styrene workers $(1,2,6,7,11)$. An increased rate of lung tumors has been reported in one other investigation - a study of boatbuilders using glass-reinforced plastics in the United States - but it was statistically nonsignificant and limited to subjects with minimal styrene exposure (10).

On balance it seems unlikely that styrene is a cause of lung cancer. If the excess mortality from the tumor did not occur by chance, it is probably due to a confounding exposure in the glass-reinforced plastics industry. From the limited range of agents encountered in the production of glass-reinforced plastics, perhaps the most likely candidate would be glass fiber dust. On the other hand, no clear excess of lung cancer has been demonstrated in studies of glass wool manufacturers (14). Further follow-up of the cohort may clarify the picture.

The findings of this survey are broadly reassuring. In a substantial group of workers, many with high exposure to styrene, we found no overall excess of mortality from cancer and, more specifically, a deficit of deaths due to lymphoma and leukemia. However, although larger than previous investigations, the study had only limited power to detect cancers with a long latency. After allowance for a latency period of 20 years from first exposure only five cancer deaths would have been expected among the hand laminators exposed to styrene for at least 12 months. The carcinogenicity of styrene is thus still in question.

\section{Acknowledgments}

We thank Ms R Barnes, Mr P Norman, and Mr M Merwood for their help with the data collection and analysis, and the staff of the NHS Central Register and National Insurance Index, who carried out the tracing.

\section{References}

1. Frentzel Beyme R, Thiess AM, Wieland R. Survey of mortality among employees engaged in the manufacture of styrene and polystyrene at the BASF Ludwigshafen works. Scand J Work Environ Health 4 (1978): suppl $2,231-239$.

2. Hodgson JT, Jones RD. Mortality of styrene production, polymerisation and processing workers at a site in northwest England. Scand J Work Environ Health 11 (1985) 347-352.

3. Hogstedt B, Hedner K, Mark-Vendel E, Mitelman F, Schutz A, Skerfving S. Increased frequency of chromosome aberrations in workers exposed to styrene. Scand J Work Environ Health 5 (1979) 333-335.

4. International Agency for Research on Cancer. Some monomers, plastics and synthetic elastomers, and acrolein. Lyon 1979. (IARC monographs on the evaluation of the carcinogenic risk of chemicals to humans, volume 19).

5. International Agency for Research on Cancer, Lyon 1982. (IARC monographs on the evaluation of the carcinogenic risk of chemicals to humans, supplement 4).

6. Meinhardt TJ, Lemen RA, Crandall MS, Young RJ. Environmental epidemiologic investigation of the styrene-butadiene rubber industry. Scand $\mathbf{J}$ Work Environ Health 8 (1982) 250-259.

7. Nicholson WJ, Selikoff IJ, Seidman H. Mortality experience of styrene-polystyrene polymerisation workers. Scand J Work Environ Health 4 (1978): suppl 2, 247-252.

8. Nordensen I, Beckman L. Chromosomal aberrations in lymphocytes of workers exposed to low levels of styrene. Hum Hered 34 (1984) 178-182.

9. Norppa H, Vainio H, Sorsa M, Belvedere G. Erythrocyte-dependent metabolic activation of styrene and induction of sister chromatid exchange in cultured human lymphocytes. Arch Toxicol (1984) suppl 7, 286-290.

10. Okun AH, Beaumont JJ, Meinhardt TJ, Crandall MS. Mortality patterns among styrene-exposed boatbuilders. Am J Ind Med 8 (1985) 193-205.

11. Ott MG, Kolesar RC, Scharnweber HC, Schneider EJ, Venable JR. A mortality survey of employees engaged in the development or manufacture of styrene-based products. J Occup Med 22 (1980) 445-460.

12. Pfaffli $P$, Vainio $H$, Hesso A. Styrene and styrene oxide concentrations in the air during the lamination process in the reinforced plastics industry. Scand $\mathrm{J}$ Work Environ Health 5 (1979) 158-161.

13. Schumacher RL, Breysse PA, Carlyon WR, Hibbard RP, Kleinman GD. Styrene exposure in the fibreglass fabrication industry in Washington State. Am Ind $\mathrm{Hyg}$ Assoc J 42 (1981) 143-149.

14. Simonato L, Fletcher AC, Cherrie J, Andersen A, Bertazzi PA, Charnay N, Claude J, Dodgson J, Estève J, Frentzel-Beyme R, Gardner MJ, Jensen OM, Olsen JH, Saracci R, Teppo L, Winkelmann R, Westerholm P, Winter PD, Zocchetti $C$. The man-made mineral fiber European historical cohort study: Extension of the follow-up. Scand J Work Environ Health 12 (1986): suppl 1, 34-47.

15. Tossavainen A. Styrene use and occupational exposure in the plastics industry. Scand J Work Environ Health 4 (1978): suppl 2, 7-13.

Received for publication: 5 January 1987 